\title{
Measuring Financial Performance for the Sustainability of Microfinance Institutions in Sierra Leone before the Ebola Outbreak
}

\section{Ezekiel K. Duramany-Lakkoh}

Institute of Public Administration and Management (IPAM), University of Sierra Leone, Freetown, Sierra Leone

Email: ezekiel.duramany-lakkoh@fulbrightmail.org

How to cite this paper: Duramany-Lakkoh, E. K. (2021). Measuring Financial Performance for the Sustainability of Microfinance Institutions in Sierra Leone before the Ebola Outbreak. Journal of Financial Risk Management, 10, 274-297.

https://doi.org/10.4236/jfrm.2021.103016

Received: June 10, 2021

Accepted: September 3, 2021

Published: September 6, 2021

Copyright $\odot 2021$ by author(s) and Scientific Research Publishing Inc. This work is licensed under the Creative Commons Attribution International License (CC BY 4.0).

http://creativecommons.org/licenses/by/4.0/

\begin{abstract}
This paper uses an accounting ratio technique to evaluate the financial performance of microfinance institutions in Sierra Leone before the Ebola outbreak, with particular emphases on profitability, sustainability, asset and liquidity management, portfolio quality, efficiency and productivity using the parameters of other deposit-taking institutions. The survey considered Community Banks (CBs) and Financial Service Associations (FSAs) and their clients in the four (4) districts of Kenema, Kailahun, Kono and Koinadugu. A sample of 3 FSAs per district and a total of 5 CBs were in the 17 institutions for the survey. Profitability basis, the performance of the sampled FSAs showed a steady improvement in ROCE, ROA and NOPM for the period 2011 to 2012 but slumped drastically in 2013. Among other reasons, the catalyst for high performance in 2011 period was that the institutions' loan portfolio grew exponentially alongside favourable interest rates coupled with low operating costs and extremely low provisions for bad loans. Operational Self-Sufficiency (OSS) in the periods 2011 and 2012, of 166\%, and $114 \%$ respectively appeared stable and encouraging but as profit dwindled, the OSS fell sharply in 2013 to 45\%; implying that the sampled FSAs could only cover $45 \%$ of operating expenses from revenue generated from operations. If the situation persists, the need to subsidize operations of the FSAs may be inevitable in the near future. Portfolio at Risk (PAR) kept an upward trend over the years. The ratio grew from 0.03 in 2010 to 0.06 in 2011 and doubled again to 0.12 in 2012, implying that the collection effort of the sampled FSAs had not been robust enough to keep pace with the growing size of loan disbursement. If the trend continues, sustainability could be threatened as the need for further huge write-off in subsequent years might be inevitable.
\end{abstract}




\section{Keywords}

Financial Performance, Financial Sustainability, Microfinance in Sierra Leone, Microfinance and Financial Performance, Sustaining Microfinance Institutions

\section{Introduction}

Microfinance has become a diverse and growing industry. Thousands of Microfinance Institutions (MFI) exit, ranging from grassroots self-help groups, village banks, community banks to commercial banks, all providing financial services to millions of low-income households around the world. In Sierra Leone, most MFIs receive support and services not only from donor agencies but also from investors, lenders, network organizations rating firms, management consulting firms and host of other financial specialized businesses. These organizations together make up a global microfinance industry. According to (Duramany-Lakkoh, 2021) Sierra Leone has attracted a lot of attention in the area of financial inclusion in the past decade, especially after the civil war in 2002. Sierra Leone benefited from various microfinance funding form International Monetary Funds, Africa Development Bank, etc. The focus of the grants was basically to promote sustainable development at all levels, including women and youth empowerment. Considering the fact that there have been a lot of inputs into financial inclusion especially from the supply-side, it is prudent to assess the impact in terms of financial performance and sustainability of selected Financial Institutions in Sierra Leone. The research covers periods before the Ebola outbreak in Sierra Leone. Most rural microfinance institutions were closed down between 2014 to middle 2016, therefore their secondary data cannot be validated for this research. The objective of this paper will be to evaluate financial performance and institutional sustainability and the risk of selected microfinance institutions in providing finance to the rural poor. Have microfinance institutions been performing financially and are they sustainable?

The study uses a case of five Community Banks (CBs) in total and 3 Financial Services Association (FSAs) per district. The CBs and FSAs should have been in existence for more than nine years and have more than 4000 beneficiaries with more than two loan circles. Both primary and secondary data were collected from the selected sample. The primary data was collected from the questioners administered to the employees of MFIs and the focus group discussions organized with the senior management of the MFIs, while the secondary data was derived from the financial statements and other management reports of the selected MFIs. A quantitative approach was used to test key financial performance variables using recognized accounting ratios. The results will be analyzed using graphs and tables. 


\section{Literature}

Development of the financial sector is very important for economic growth in Sierra Leone (Duramany-Lakkoh, 2020), and the establishment of microfinance institutions has contributed to financial inclusions especially in developing countries. (McKinnon, 1973; Levine, 1997) argues that operational efficiency in financial institutions will reduce information and transactions costs and hence improves savings and investment decisions. Micro financing has become an important feature for the promotion of Small and Medium Size Enterprises in Sierra Leone, at a time when the MFI industry is thriving globally. Rural Finance and Community Improvement Programme (RFCIP) was identified by the International Fund for Agricultural Development (IFAD) for Sierra Leone to reduce poverty in the rural areas especially through provision of access of finance. The rural poverty in Sierra Leone is wide spread and it is estimated $70 \%$ of the population live below the poverty line (PRSP I, 2005).

Financial analysis unveils the significant of the operating statements and the statement of financial positions by using the elements in the financial statements to measure performance in the form of profitability, liquidity, solvency and other value and risks related ratios. According to (Sangmi \& Nazir, 2010) Financial Performance analysis is a process of evaluating the relationship between components parts of a financial statement to obtain a better understanding of a firm's position and performance. Similarly, (Khan \& Jain, 1997) defined ratio analysis as the systematic use of ratio to interpret financial performance so that the strength and weakness of firm as well as its historical performance and current financial condition can be determined.

(Tarawneh, 2006), argues that financial performance describes the efficiency of businesses in the use of business assets. Performance and sustainability ratios have long been used as indicators to measure financial stability of microcredit institutions (Woller, 2000). Return on Capital Employed (ROCE), Returned on Equity (ROE), Returned on Assets (ROA) and Net Operating Profit Margins are four important variables used to measure profitability in microfinance institutions, while sustainability is best measured using Operating Self Performance (OSS), Portfolio at Risk (PAR), Risk Coverage Ratio (ROR) and Loan Written off Ratio (LRO). The scope of financial performance analysis depends on the background of the industry and the user of the information. While some users are more concerned with investment ratios, others are concerned with profitability and sustainability. Financial institutions can boost operational performance by adopting strategies that will improve profitability. According to (McKinnon, 1973; Levine, 1997) financial ratios analysis can measures various aspects of the performance and analyzes fundamentals of a microfinance institution which will also be used by management and investors to determine weaknesses and strength within the operating of small and medium scale financial institutions. (Ho \& Zhu, 2004) also commended on the evaluation of a company's performance and its focus on operational effectiveness and efficiency. He further argues that the strength of its financial performance might directly influence the 
company's survival.

\section{Method}

This study used ratio analysis to describe and analyze financial data from the sampled FSAs and CBs for the period of 2010 to 2013. The study assesses the institutions under the following four important areas of rural finance:

1) Profitability and Sustainability;

2) Asset and Liquidity Management;

3) Portfolio Quality;

4) Efficiency and Productivity.

Under these parameters, especially in relation with the CBs, certain financial ratios are calculated and benchmarked against some performance indicators in accordance with Banking Supervision requirements of the Bank of Sierra Leone (BSL) for Other Deposit Taking Institutions (ODTI). The study uses the (CGAP, 2009) Financial Analysis for Microfinance Institutions as shown in Table 1. The information presented in the table defines the accounting ratios and measurement criteria used in the analysis of results obtained.

The survey considered CBs and FSAs and their clients in the four (4) districts of Kenema, Kailahun, Kono and Koinadugu. These districts were selected on the basis that they belong to a group of districts that benefited from previous other projects like Agricultural Sector Rehabilitation Projects (ASREP) and Rehabilitation and Community-based Poverty Reduction Project (RCPRP) which to a great extent established some visible foundation for the RFCIP. These districts were singled out on the two levels (i.e. social and area) targeting strategy with Koinadugu classified as the poorest of the districts slated to benefit from the core and support component of rural finance services and community development. Whilst the other three districts of Kailahun, Kono, and Kenema benefited from the core support component of rural finance services only.

A sample of 3 Financial Services Associations (FSAs) per district and a total of 5 Community Banks (CBs) were the 17 institutions for the survey. The sampled CBs included 2 of the 6 CBs taken over from Bank of Sierra Leone (BSL) for rehabilitation and reconstruction and $3 \mathrm{CBs}$ established by the RFCIP. Table 2 above gives a sample frame of the sampled CBs and FSAs per district.

\section{Presentation and Analysis of Results}

\subsection{Performance of the Financial Services Associations}

Profitability and Sustainability

The study considers the following indicators in assessing profitability and sustainability of the FSAs and CBs over the years: 1) Return on Capital Employed (ROCE); 2) Return on Assets (ROA); 3) Net Operating Profit Margin (NOPM); 4) Operational, Self-Sufficiency (OSS); and 5) Financial Self-Sufficiency (FSS). Table 1 shows profitability and sustainability indicators for FSAs. Table 3 shows the profitability ratios. 
Table 1. Definition of accounting ratios measuring tools.

\begin{tabular}{ccc}
\hline Ratio & Formula & Implication to MFIs \\
\hline & Profitability and Sustainability &
\end{tabular}

\begin{tabular}{|c|c|}
\hline $\begin{array}{c}\text { Return on } \\
\text { Capital Employed }\end{array}$ & $\begin{array}{l}\text { Net operating profit/Total } \\
\text { assets-short-term liabilities }\end{array}$ \\
\hline $\begin{array}{l}\text { Return on } \\
\text { Asset }\end{array}$ & $\begin{array}{c}\text { Net operating } \\
\text { profit/Average assets }\end{array}$ \\
\hline Profit Margin & $\begin{array}{c}\text { Net operating } \\
\text { profit/Operating revenue }\end{array}$ \\
\hline $\begin{array}{c}\text { Operating } \\
\text { Self Sufficiency }\end{array}$ & $\begin{array}{c}\text { Operating revenue/(Financial } \\
\text { expenses + Loan loss } \\
\text { provision exp + Operating } \\
\text { expenses) }\end{array}$ \\
\hline $\begin{array}{c}\text { Capital } \\
\text { Adequacy }\end{array}$ & $\begin{array}{c}\text { (Tier } 1 \text { Cap }+ \text { Tier } 2 \text { Cap)/Risk } \\
\text { weighted assets } \\
\text { Where: Tier } 1 \text { cap }=\text { ordinary } \\
\text { share }+ \text { audited rev+ intangible assets } \\
\text { Tier } 2 \text { cap }=\text { unaudited retained } \\
\text { earnings+ general prov. for bad debt } \\
\text { Risk weighted assets }=>\text { assigning } \\
\text { weight to assets such as customer loan; } \\
\text { debenture }=1 \text {; govt. debt }=0\end{array}$ \\
\hline
\end{tabular}

Measures the reward of long term capital. The assumption is that the more capital that is used the higher the profit to be achieved before finance charge and taxes.

Measures how well MFIs uses its total assets to generate returns.

Measure what percentage of operating revenue remains after all financial, loan-loss provision, and operating expenses are paid.

Measure how well MFIs cover cost through operating revenues. In addition to operating expenses, it is recommended that financial expenses and Loan-loss provisions be included in this calculation, as they are normal (significant) cost of operation.

Measures the extent to which the MFIs can cover or meet the business risk or shock without going out of business. The Basel minimum requirement now adopted by central banks of many countries is $8 \%$.

That is MFIs should be able to cover at least $8 \%$ of their risk assets.

\section{- Asset and Liquidity Management}

\begin{abstract}
Yield on Gross Loan Portfolio
\end{abstract}

Cost of Fund Ratio
Cash financial revenue from loan portfolio/Average gross loan portfolio

Interest and fee expenses on funding liabilities/Average funding Liabilities
Indicates the gross loan portfolio's ability to generate cash financial revenue from interest, fees, and commission.

Gives a blended interest rate for MFIs funding liabilities.

Funding liabilities include all liabilities used to finance MFI financial assets.

\section{- Portfolio Quality}

$\begin{array}{cc}\begin{array}{c}\text { Portfolio } \\ \text { at Risk }\end{array} & \begin{array}{c}\text { Portfolio at risk (30 days) plus } \\ \text { restructured loans/Total } \\ \text { outstanding gross portfolio }\end{array} \\ \begin{array}{c}\text { Risk } \\ \text { Coverage } \\ \text { Ratio }\end{array} & \begin{array}{c}\text { Loan loss provisions or } \\ \text { reserves /Outstanding } \\ \text { balance in arrears over 30 days }\end{array}\end{array}$

This is the outstanding amount of all loans that have one or more installments of principal past due more than 30 days.

Shows the portfolio at risk that is covered by actual loss loans reserves. 


\section{Continued}

Write off Ratio

\author{
Value of loan written \\ off/Average gross \\ loan portfolio
}

\section{- Efficiency and Productivity}

Loan Officer

Productivity

Personnel

Productivity

Average

Disbursement

Loan Size

Average

Outstanding

Loan Size
Number of active borrowers/Number of loan officers

Number of active borrowers/Number of Personnel

Value of loans disbursed/Total number of loans disbursed during period

Gross loan portfolio/Total loans outstanding
Represents the percentage of MFIs' loans that have been removed from the balance of gross loan portfolio because they are unlikely to be repaid. A high ratio may indicate a problem in the IMFs collection effort.

Measures the average caseload of each loan officer. This is a common ratio, but is difficult to compare among MFIs when their definitions of loan officer vary. MFIs may also substitute the number of loans outstanding as a surrogate for number of active borrowers and the number of financial service officers for loan officers.

Measure all overall productivity of total MFI human resources in managing clients who have an outstanding loan balance and are thereby contributing to the financial revenue of the MFI.

Measure the average loan size that is disbursed to clients. MFIs should be careful to distinguish between disbursement loan size and outstanding loan size.

Measure that outstanding loan balance by client, which may be significantly less than the average disbursement loan size. It is frequently compared to per capital GDP as a rough proxy for the income level of MFIs clientele.

Source: (World Bank Group, 2009) Consultative Group to Assist the Poor.

Table 2. The sample frame of community banks and financial services association.

\begin{tabular}{|c|c|c|c|c|c|c|c|c|c|}
\hline District & \multicolumn{2}{|c|}{ Kenema } & \multicolumn{2}{|c|}{ Kono } & \multicolumn{2}{|c|}{ Kailahun } & \multicolumn{2}{|c|}{ Koinadugu } & \multirow{2}{*}{ Total } \\
\hline Established by & BSL & RFCIP & BSL & RFCIP & BSL & RFCIP & BSL & RFCIP & \\
\hline Support from rural financial services & \multicolumn{2}{|c|}{ Yes } & \multicolumn{2}{|c|}{ Yes } & \multicolumn{2}{|c|}{ Yes } & \multicolumn{2}{|c|}{ No } & \\
\hline Number of CB selected & Nil & 1 & Nil & 1 & 1 & 1 & 1 & Nil & 5 \\
\hline Number of FSA selected & NA & 3 & NA & 3 & NA & 3 & NA & 3 & 17 \\
\hline
\end{tabular}

Source: Researcher's data.

Table 3. Profitability and sustainability indicators.

\begin{tabular}{cccccc}
\hline Ratio & Avg & 2010 & 2011 & 2012 & 2013 \\
\hline Return on Capital Employed (ROCE) & 6.93 & 3.17 & 14.34 & 11.70 & 0.55 \\
\hline
\end{tabular}


Continued

\begin{tabular}{cccccc}
\hline Return on Equity (ROE) & 49.5 & 19.94 & 43.15 & 56.83 & 5.08 \\
Return on Asset (ROA) & 6.34 & 3.08 & 12.08 & 10.90 & 0.51 \\
Net Operating Profit Margin (NOPM) & 42.60 & 50.86 & 60.95 & 51.27 & 2.33 \\
Operating Self Sufficiency (OSS) & 53 & 94 & 166 & 114 & 45 \\
\hline
\end{tabular}

Source: Researcher's data.

\section{1) Profitability}

On the basis of profitability, performance of the sampled FSAs showed a steady improvement in ROCE, ROA and OPRM for the period 2011 to 2012 but slumped drastically in 2013. The profitability indices peaked in 2011 and declined in 2012. Among other reasons, the catalyst for high performance in 2011 period was that the institutions' loan portfolio grew exponentially alongside favourable interest rates coupled with low operating costs and extremely low provisions for bad loans. However, in the periods thereafter, the FSAs experienced the downside of overtrading. Managing the size of operations became challenging and debtors' collection period lengthen and capital efficiency threatened. Compliance issues became crucial for the operations of the institutions with high customer delinquencies experienced. Average operating profit of the sampled institutions fell from $50.86 \%$ in 2011 to $2.33 \%$ in 2013 . Figure 1 shows the trend in the profitability indices of the sampled FSAs.

Investigating the effect of each institution in the sample revealed that most of FSAs reported profit in the 2013 period but some made significant losses. The most significant was that of Gawra FSAs in Kenema District which reported a loss of SLL 147 million in the 2013 period. Most of the FSAs started writing-off bad loans in 2012 and almost all of them wrote off huge amount of bad loans totalling SLL 558 million in the 2013 period. This decision negatively affected the 2013 performance with regard all profitability indices keeping the ROA at its lowest of $0.51 \%$.

\section{2) Sustainability}

Making the RFCIP project sustainable implies that FSAs have to be operational and financial self-sufficient. The OSS ratio shows the extent to which the sampled FSAs covered their operational expenses out of revenue from operations. In the periods 2011 and 2012, the OSS of 166\% and 114\% respectively appeared stable and encouraging but as profit dwindled, the OSS fell sharply in 2013 to $45 \%$ implying that the FSAs can only cover $45 \%$ of its operating expenses through revenue generated from operations. If the situation persists, the need to subsidize operations of the FSAs may be inevitable.

\subsection{Portfolio Quality}

According to data collected, the sampled FSAs risk management strategy was below standard. Table 4 provides ratios on portfolio quality. 


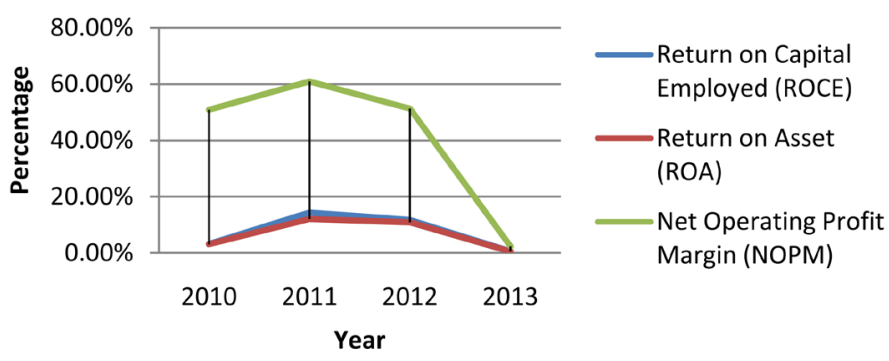

Figure 1. Profitability indices of FSAs. Source: Researcher's data.

Table 4. Portfolio quality ratios.

\begin{tabular}{cccccc}
\hline & Avg & 2010 & 2011 & 2012 & 2013 \\
\hline Portfolio at Risk & 0.09 & 0.03 & 0.06 & 0.12 & 0.14 \\
Risk Coverage Ratio & 0.62 & 0.00 & 0.03 & 0.36 & 0.63 \\
Loan Written Off Ratio & 0.09 & 0.00 & 0.00 & 0.04 & 0.19 \\
\hline
\end{tabular}

Source: Researcher's data.

\subsubsection{Portfolio at Risk}

This ratio had kept an upward trend over the years. The ratio grew by $100 \%$ of its lowest level of 3\% in 2010 to $6 \%$ in 2011 and doubled to $12 \%$ in 2012 and rose to $14 \%$ in 2013. This implies that the collection effort of the FSAs had not been robust enough to keep pace with the growing rate of loan disbursement. If the trend continues, sustainability could be threatened as the need for further huge write-off in subsequent years might be inevitable.

\subsubsection{Risk Coverage Ratio}

After moving away from a more optimistic outlook of zero provision for bad loans in 2010 basically because the FSAs were new, the sampled FSAs made some minimal provision in 2011 covering just 3\% of risk loans portfolio. Bad loans provision rose sharply in 2012 covering $36 \%$ of the portfolio at risk; and almost doubled to $63 \%$ in 2013. In essence, the FSAs may have substantially provided for future loans that may be irrecoverable. However, this decision may erode the bottom line and introduce some complacency in the collection effort.

\subsubsection{Loan Written-Off Ratio}

Similarly, for the very first time since commencement of operations, in 2012, the sampled FSAs impaired their loan portfolio by only $4 \%$ of all loans outstanding. In 2013 , loans written-off rose sharply to $19 \%$. Essentially, loss provisions are driven by age of loan outstanding beyond the duration period. The magnitude of loss written-off in recent successive years threatens sustainability. It could to a large extent be a cause for concern about the policy regime in place for loan portfolio management of the FSAs.

\subsubsection{Asset Liquidity Management}

However, in spite of the questionable risk management strategy, the sampled FSAs maintained a good level of assets and liquidity management from two 
perspectives-yield on loan portfolio and cost of fund ratios. Table 5 shows the liquidity ratios for the four years.

\subsubsection{Yield on Loans Portfolio}

The amount of cash received on loans disbursed improved steadily since commencement of operations. After taking off at $9 \%$ in 2010, the yield on the loans given out rose to $16 \%$ in 2011 and peaked to $21 \%$ in 2012 but fell to $17 \%$ in 2013 . The key driver of yield on loan is interest rates charged. The result shows that relatively the FSAs received better rates for loans given out over the years especially in the 2012 period.

\subsubsection{Cost of Fund Ratio}

Total funds liability acquired to provide FSAs with much funds for intermediation includes deposits for safe keeping, shares from individuals and institutions in the communities and refinance from other MFIs. According to data provided, during the periods under study, the FSA received a total of about SLL 2.0 billion at an average rate of $11 \%$ as refinance for on-lending to clients. The principle behind this capitalization effort is to keep cost of capital at minimum level to augment the capital base of the FSAs and somehow subsidize the rate of interest charged to clients. In 2010, none of the sampled FSAs received such fund. In 2011, a total fund available from the various sources amounted to SLL641million at average interest rate of $8 \%$; SLL 794 million was charged at an average rate of $10 \%$ in 2012. The average cost of capital increased to $17 \%$ in 2013 and caught up with the yield on loan portfolio for the same period. However, the FSAs gave out loans to clients at an average rate of $22 \%$ over the period to 2013. Figure 2 shows the gap between charge on funding liabilities and yield on loans disbursed.

\subsection{Efficiency and Productivity}

In order to get a clear understanding of how efficient and productive the

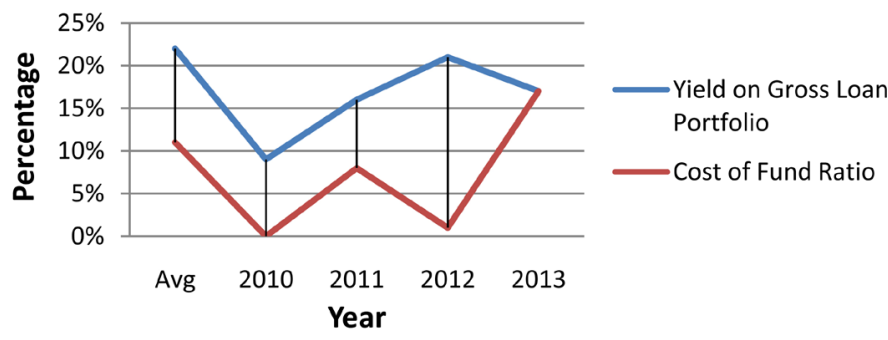

Figure 2. Yield on gross loan and cost of fund. Source: Researcher's data.

Table 5. Asset and liquidity management ratios.

\begin{tabular}{cccccc}
\hline & Avg & 2010 & 2011 & 2012 & 2013 \\
\hline Yield on Gross Loan Portfolio & 0.22 & 0.09 & 0.16 & 0.21 & 0.17 \\
Cost of Fund Ratio & 0.11 & 0.00 & 0.08 & 0.10 & 0.17 \\
\hline
\end{tabular}

Source: Researcher's data. 
sampled FSAs had been over the years in delivering services of access to finance, the survey considers certain indicator as shown in Table 6.

\subsubsection{Loan Officer Productivity}

The proportion of client to loan officer in the sampled FSAs had been on the increase. In 2010, there were 40 clients to an officer, the figure rose to about 47 clients to one officer in 2011, 70 clients to a loan officer in 2012, and the proportion more than doubled to 157 clients per officer in 2013. The study is not aware of the industry standard on an ideal clients to officer ratio; however, the implication for a growing proportion is obvious; the larger the ratio the lesser the intensity of the monitoring and the weaker the collection effort. Perhaps this situation could be partly blamed for the growing amount of outstanding loans requiring substantial bad loans provisions and the consequent huge write off in the recent years.

\subsubsection{Operating Expenses Ratio}

Another efficiency indicator used in the survey is the proportion of operating expenses to gross loans disbursed. In 2010, the amount expended per loan disbursed by the sampled FSAs was only $8 \%$; the figure almost doubled to $14 \%$ in 2011; rose slowly by just $1 \%$ in 2012 and fell to $12 \%$ in 2013.The expense ratio gets better as the loan size increases. The FSAs were to expand loan portfolio to bring the ratio down further. However, expanding loan portfolio should be accompanied by stringent loan collection procedures and effort.

\subsubsection{Cost Per Borrower}

The survey also measures cost in relation to borrowers in the sampled FSAs. The result shows a steady rise since 2010 which implies that the FSAs were spending more to cover the loan clients over the years. The most obvious reason was that the institutions struggled to manage costs that vary with keeping track of the loan clients.

\subsubsection{Loan Size Progression}

One of the indicators used by the survey to assess growth in the sampled FSAs'

Table 6. Efficiency and Productivity.

\begin{tabular}{cccccc}
\hline & Avg & 2010 & 2011 & 2012 & 2013 \\
\hline Loan Officer Productivity & 84 & 40.15 & 46.53 & 70.33 & 157.46 \\
Operating Expenses Ratio & 0.13 & 0.08 & 0.14 & 0.15 & 0.12 \\
Cost Per Borrower (Le) & $84,000.09$ & $61,931.51$ & $87,350.45$ & $74,411.53$ & $90,246.79$ \\
Average Disbursement & & & & & \\
Loan Size (Le) & $831,744.60$ & $673,510.59$ & $1,409,379.10$ & $1,355,030.45$ & $975,724.34$ \\
Average Loan Outstanding (Le) & $645,868.35$ & $471,042.96$ & $745,343.88$ & $958,619.47$ & $505,442.22$ \\
Average loan uncollected (\%) & 0.78 & 0.70 & 0.53 & 0.71 & 0.52 \\
\hline
\end{tabular}

Source: Researcher's data. 
capacity to provide access to finance is the progression in average loan sizes disbursed over the years. Starting with average disbursement of SLL 673,510.59 (approximately US\$153) in 2010, the average size of loan disbursed more than doubled to SLL 1,409,379.10 in 2011, fell slightly to SLL 1,355,030.41 in 2012, and decreased further to SLL 975,724.34 in 2013. Essentially, growth in loan sizes over the years is a reflection of the multiplier effect of the programme intervention resulting in expansion of the sizes of income generating activities. However, there had been stagnation in growth of loan sizes and probably in the sizes of income generating activities as well due to one of the following reasons. First, due to the high uptake in 2011, businesses were sufficiently funded and there were few new entrants with bigger requests for loans. Second and perhaps the most obvious reason was that due to the growing average outstanding loans, the FSAs in the sample were unable to meet demands for bigger loans with the funds available. Finally, poor business performance over the years could have hampered the ability of loan clients to make timely repayment and request for bigger loan amounts.

Also, the amount of average loan outstanding had been on the increase since 2010. According to the survey, the FSAs were on average able to collect only $22 \%$ of loans given out during the period to 2013. In 2010, $70 \%$ of loans disbursed were uncollected, there was marked improvement in 2011 with $47 \%$ collected, the amount uncollected rose again to $68 \%$ in 2012 and improved to $52 \%$ in 2013. There could be several reasons for the growing outstanding average loans over the years. The first and most obvious could be the poor intensity of the monitoring and collection effort. The second reason might be the timing of the loans disbursed; based on the duration period, loans issued by the latter period of the year could straddle into another year. Figure 3 presents average loan size disbursed and outstanding.

\subsubsection{Employment Effect (FSAs Clients)}

Table 7 shows the increase in demand for labour of the income generating

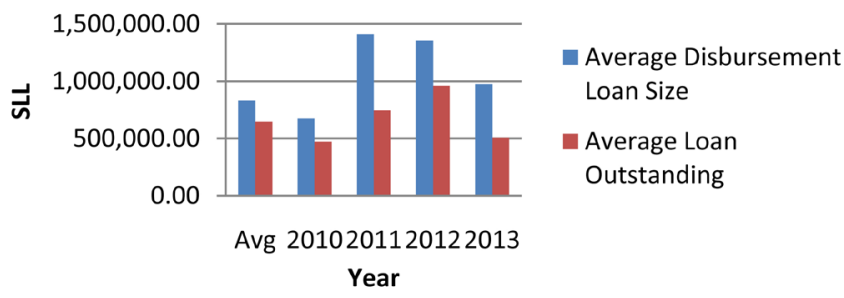

Figure 3. Loan size progression.

Table 7. Employment effect of income generating activities.

\begin{tabular}{ccccc}
\hline & 2010 & 2011 & 2012 & 2013 \\
\hline Number of active borrowers & 803 & 1675 & 2441 & 5306 \\
Incremental demand for labour days & 167,024 & 348,400 & 507,728 & $1,103,648$ \\
Employment effect in incremental persons years & 642 & 1340 & 1953 & 4245 \\
\hline Source: Researcher's data. & & & &
\end{tabular}


activities created due to the number of loans disbursed by the sampled FSAs over the period to 2013. Loans accessed by clients of the FSAs led to consistent growth in incremental demand for labour days and employment effect in incremental person years.

\section{Performance of the Community Banks}

\subsection{Profitability}

Table 8 shows computation of some profitability and sustainability indicators of the sampled CBs.

According to the survey, the CBs started-off with negative average profit of SLL 169 million in 2010. As expected, at the early stage of the programme intervention, operating expenses was above operating revenue; all profitability indices were negative in 2010. However, with improved performance, the operations of the CBs turned around and profit levels were good in 2011 to 2013 as shown in Figure 4.

Net operating profit margin grew by more than $105 \%$ to $26.13 \%$ in 2011 ; ROCE rose by almost $14 \%$ from $-8.49 \%$ to $5.22 \%$ and kept growing to $15.61 \%$ in 2013. Also, ROA improved by almost $13 \%$ to $4.92 \%$ in 2011 and continued on the rise to $14.30 \%$ in 2013 way above the BSL minimum MIX requirement of $2.1 \%$.

\subsection{Sustainability}

The survey uses two key indicators to show the extent to which the capital structure of the sampled CBs could sustain operations into foreseeable future without the need for subsidy or risk of shutting down prematurely. Table 9 shows OSS ration and CAR of the sampled CBs.

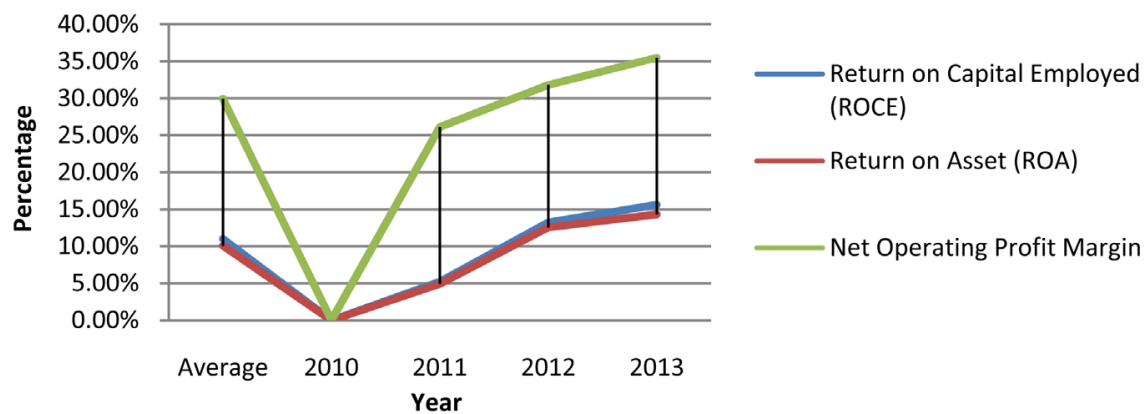

Figure 4. Profitability indices trend (\%).

Table 8. Profitability indices.

\begin{tabular}{cccccc}
\hline Ratios & Average & 2010 & 2011 & 2012 & 2013 \\
\hline Return on Capital Employed (ROCE) & 10.99 & -8.49 & 5.22 & 13.23 & 15.61 \\
Return on Asset (ROA) & 10.07 & -8.49 & 4.92 & 12.54 & 14.30 \\
Net Operating Profit Margin & 29.91 & -79.05 & 26.13 & 31.79 & 35.48
\end{tabular}

Source: Researcher's data. 
Table 9. Sustainability indices.

\begin{tabular}{cccccc}
\hline & Avg & 2010 & 2011 & 2012 & 2013 \\
\hline Operational Self-Sufficiency (OSS) & 142 & 49 & 79 & 130 & 201 \\
Capital Adequacy Ratio (CAR) & 2.51 & 0.26 & 4.41 & 4.00 & 4.61 \\
\hline
\end{tabular}

Source: Researcher's data.

According to the BSL minimum capital requirement as contained in the Other Deposit Taking Guidelines, CBs should have minimum share capital value of SLL 1 billion. However, the survey found out that the sum of average paid-up share capital of the CBs as at 2013 was SLL 472,533,800; a shortfall of about SLL 520 million. The situation was exacerbated by a weak CAR averaging just $2.51 \%$; way below the BSL minimum requirement of $8 \%$. The low CAR average was significantly influenced by the 2010 ratio of less than $1 \%$. However, the situation significantly improved in the subsequent years and the CAR now stood at almost $5 \%$ as at 2013 . The implication is that as at 2013 , the banks could afford to lose only $5 \%$ of their capital to withstand any shock that may threaten continuity. Therefore it is extremely important that banks improve their CAR to be in position to cover loss and stay in business.

In the early period of 2011 and 2012 the CBs could only cover the $49 \%$ and $79 \%$ of operational expenses out of revenue from operations respectively. The ratio improved significantly in the 2012 and 2013 periods with the sampled CBs now able to cover $130 \%$ and $201 \%$ respectively surpassing the BSL OSS minimum Mix requirement of $112 \%$.

\subsection{Portfolio Quality}

Table 10 shows indices of the quality of the sampled CBs portfolio.

\subsubsection{Portfolio at Risk}

After a slight decrease in 2011, PAR had kept an upward trend over the years. The ratio grew by almost $3 \%$ in 2012 to $8.21 \%$ and rose further to $9.65 \%$ in 2013 . Notably, the survey found out that according to data provided, the sampled CBs had written-off no bad loans over the period understudy. However, the growing PAR trend implies that the collection effort of the CBs could not keep pace with the growing loan disbursement. If the trend continues, sustainability would become an issue for the CBs and the likelihood for write-off of bad loans in subsequent years could be inevitable.

\subsubsection{Risk Coverage Ratio}

What could be seen as good practice by the sampled CBs was the ample provision for bad loans over the years. In 2010 , the CBs could cover more than $72 \%$ of their portfolio at risk. The ratio dropped drastically to its lowest of $8.55 \%$ in 2012 but rose to almost $22 \%$ in 2013.

\subsection{Asset Liquidity Management}

The survey assesses the CBs on two indices in relation with asset liquidity 
Table 10. Portfolio quality.

\begin{tabular}{cccccc}
\hline & Avg & 2010 & 2011 & 2012 & 2013 \\
\hline Portfolio at Risk & 7.66 & 7.50 & 5.29 & 8.21 & 9.65 \\
Risk Coverage Ratio & 16 & 72.31 & 15.91 & 8.55 & 21.96 \\
\hline
\end{tabular}

Source: Researcher's data.

management-yield on gross loan portfolio and cost of fund ratio as shown in Table 11.

\subsubsection{Yield on Gross Loan Portfolio}

Cash revenue from loan portfolio of the CBs fell slightly from 16\% in 2010 to $11 \%$ in 2011 but doubled to $22 \%$ in 2012 and rose by additional $6 \%$ to $25 \%$ in 2013. As mentioned earlier, the key driver of the yield on gross loan portfolio is rate of interest charged by the CBs on loans given out to clients. In essence, the average rate of interest received by the sampled CBs over the period of the survey was $23 \%$.

\subsubsection{Cost of Fund Ratio}

Just like the FSAs, the CBs received refinancing from inter-community-banks arrangement, the Apex bank and other funding sources. The cost of re-financing the CBs had been extremely minimal according to data provided for the survey and when matched with the yield on loans showed a huge difference between the averages of $22 \%$ as shown in Figure 5, what this means is that the gap provided potential for the CBs to attract more clients with low interest rates and expand the loan portfolios.

\subsection{Efficiency and Productivity}

The study assesses the sampled CBs on six efficiency and productivity indicators as shown in Table 12.

\subsubsection{Loan Officer Productivity}

The proportion of loan clients (borrowers) to officer in the sampled CBs had been increasing since 2010. The ratio almost tripled in 2011 to 99 clients to an officer. In 2012, 127 clients were handled by one loan officer, and the figure almost doubled to 223 clients in 2013. As mentioned earlier, the study is not aware of an ideal industry standard on loan clients to an officer ratio. But the growing proportion could reduce the intensity of the monitoring and collection effort.

\subsubsection{Operating Expenses Ratio}

The survey assesses the proportion of operating expenses to gross loans disbursed. In 2010, 20\% of operating expenses were spent on loans disbursed by the sampled CBs. The ratio more than doubled to $50 \%$ in 2011 ; fell slightly by $7 \%$ in 2012. In 2013, the ratio was $22 \%$. The expense ratio got better as the loan disbursed increased. However, expanding loan portfolio should be accompanied by stringent collect procedures and effort. 


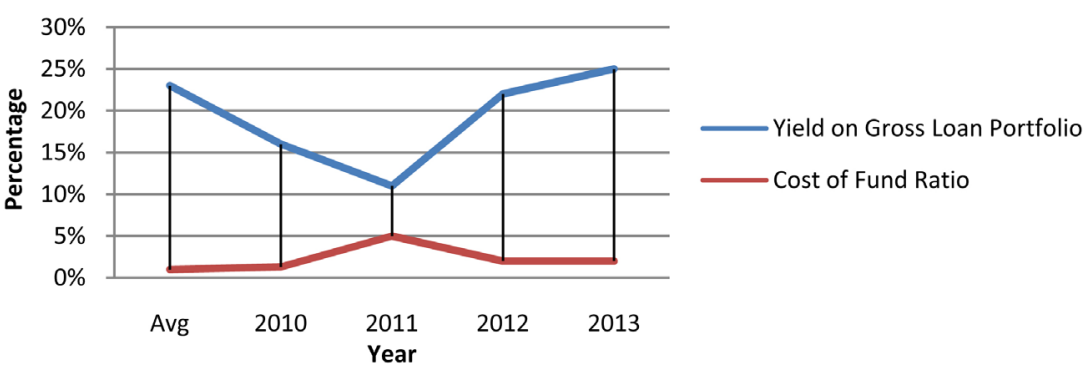

Figure 5. Yield on gross loan and cost of fund ratio.

Table 11. Asset liquidity management.

\begin{tabular}{cccccc}
\hline & Avg & 2010 & 2011 & 2012 & 2013 \\
\hline Yield on Gross Loan Portfolio & 0.23 & 0.16 & 0.11 & 0.22 & 0.25 \\
Cost of Fund Ratio & 0.01 & 0.013 & 0.05 & 0.02 & 0.02 \\
\hline
\end{tabular}

Source: Researcher's data.

Table 12. Efficiency and productivity indices.

\begin{tabular}{cccccc}
\hline & Avg. & 2010 & 2011 & 2012 & 2013 \\
\hline Loan Officer Productivity & 121 & 38 & 99 & 127 & 223 \\
Operating Expenses Ratio & 0.30 & 0.20 & 0.50 & 0.43 & 0.22 \\
Cost per Borrower & $430,456.89$ & $159,617.27$ & $211,207.47$ & $507,887.01$ & $523,791.05$ \\
Cost per Client & $102,475.05$ & $105,937.28$ & $82,598.36$ & $129,633.19$ & $94,212.17$ \\
Avg Disbursement Loan Size & $1,463,726.52$ & $1,014,285.71$ & $1,180,994.71$ & $1,506,508.70$ & $1,589,438.48$ \\
Avg Outstanding Loan Size & $820,659.75$ & $1,364,959.05$ & $505,908.12$ & $736,363.10$ & $905,364.58$ \\
Uncollected (\%) & 0.56 & 1.35 & 0.43 & 0.49 & 0.57 \\
\hline
\end{tabular}

Source: Researcher's data.

\subsubsection{Cost per Borrower and Cost per Client}

The survey also measured cost in relation to active borrowers and clients in the sampled CBs. The result shows a steady rise in the cost per borrower since 2010 which implies that the CBs were spending more to cover the loan clients over the years. However, on the contrary, the cost when depositors were included fell in 2011 but rose slightly in 2012 and fell again in 2013. The most obvious reason was that the institutions struggled to manage costs on keeping track of borrowers very little was needed with costs relating to depositors.

\subsubsection{Loan Size Progression}

The survey assesses growth in the sampled CBs by looking at capacity to provide access to finance through progression in average loan sizes disbursed over the years. Starting with average disbursement of SLL 1,014,285.71 (approximately US\$230) in 2010, the average size of loan disbursed grew slowly to SLL 1,180,994.70 in 2011, and eventually rose to SLL 1,589,489.48 in 2013. As mentioned earlier, growth in loan sizes over the years was a reflection of the attainment of the 
access to finance objective of the programme intervention resulting in expansion of the sizes of income generating activities though slower in the CBs than observed with clients of the FSAs.

According to data provided, the average loan outstanding was higher about 1.35 times more than average loan size disbursed in 2010 perhaps due to outstanding loans carried over from previous years. The situation significantly improved subsequently and the CBs were on average able to collect $57 \%$ of loans given in 2011. In 2012, 51\% of loans disbursed were collected; and $43 \%$ collected in 2013. There could be several reasons for improvement in average loans collected over the years. The first and most obvious reason could that the CBs intensified monitoring and collection effort due to capacity building enhanced by the programme intervention. The second reason might be the timing of previous loans disbursed; based on the duration period, loans issued during the latter period of previous years fell due and collected in due and collected in subsequent years (Figure 6).

\subsection{Employment Effect (FSAs Clients)}

Table 13 shows increase in demand for labour of the income generating activities created due to the number of loans disbursed by the sampled CBs over the period to 2013. Loans accessed by clients of the CBs led to consistent growth in incremental demand for labour days and employment effect in incremental person years.

\section{Summary of Findings and Conclusion}

Profitability basis, the performance of the sampled FSAs showed a steady improvement in ROCE, ROA and NOPM for the period 2011 to 2012 but

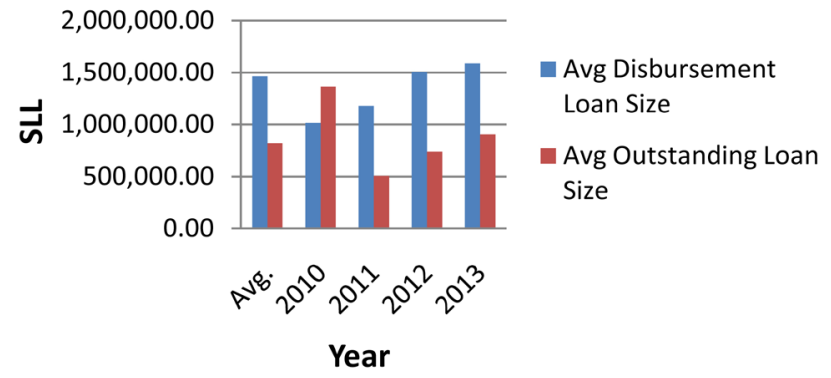

Figure 6. Average loan size progression and collected.

Table 13. Employment effect of income generating activities.

\begin{tabular}{ccccccc}
\hline & 2010 & 2011 & 2012 & 2013 & Total & Avg \\
\hline CBs Number of Active Borrowers & 1343 & 3080 & 4558 & 7,351 & 16,332 & 4083 \\
$\begin{array}{c}\text { Increment demand for labour days } \\
\text { Employment effect }\end{array}$ & 279,344 & 640,640 & 948,064 & $1,529,008$ & $3,397,056$ & 849,264 \\
$\begin{array}{c}\text { En incremental persons years } \\
\text { in }\end{array}$ & $1,074.40$ & $2,464.00$ & $3,646.40$ & $5,880.80$ & 13,066 & $3,266.40$
\end{tabular}

Source: Researcher's data. 
slumped drastically in 2013. Among other reasons, the catalyst for high performance in 2011 period was that the institutions' loan portfolio grew exponentially alongside favourable interest rates coupled with low operating costs and extremely low provisions for bad loans.

Compliance issues became crucial for the operations of the institutions as high customer delinquencies were experienced; a substantial amount of loans about SLL 588 million were written off in 2013. Average operating profit of the sampled institutions of SLL 282 million reported in 2011 plummeted to SLL 16.83 million in 2013. Although most of the FSAs reported profits in the 2013 period, some made significant losses. The most significant was that of Gwara FSA which reported a loss of SLL147 million in the 2013 period.

The value of loans written-off negatively affected the 2013 performance with regard to all profitability indices dropping the ROA to its lowest of $0.51 \%$.

Operational Self-Sufficiency (OSS) in the periods 2011 and 2012, of 166\%, and $114 \%$ respectively appeared stable and encouraging but as profit dwindled, the OSS fell sharply in 2013 to 45\%; implying that the sampled FSAs could only cover $45 \%$ of operating expenses from revenue generated from operations. If the situation persists, the need to subsidize operations of the FSAs may be inevitable in the near future.

Portfolio at Risk (PAR) kept an upward trend over the years. The ratio grew by $100 \%$ of its lowest level of $3 \%$ in 2010 to $6 \%$ in 2011 and doubled to $12 \%$ in 2012 and rose to $14 \%$ in 2013 implying that the collection effort of the sampled FSAs had not been robust enough to keep pace with the growing size of loan disbursement. If the trend continues, sustainability could be threatened as the need for further huge write-off in subsequent years might be inevitable.

Similarly, for the very first time since the commencement of operations, in 2012, the sampled FSAs impaired their loan portfolio by only $4 \%$ of all loans outstanding. In 2013, loans written off rose sharply to $19 \%$. The magnitude of loss written-off in recent successive years threatens sustainability. It could to a large extent be a cause for concern about the policy regime in place for loan portfolio management by the FSAs.

In spite of the questionable risk management strategy, the sampled FSAs maintained a good level of assets and liquidity management from two perspectives-yield on loan portfolio and cost of fund ratios. The amount of cash received on loans disbursed improved steadily since the commencement of operations. After taking off at $9 \%$ in 2010, the yield on the loans given out rose to $16 \%$ in 2011 and peaked at $21 \%$ in 2012 but fell to 17\% in 2013.

During the periods under study, the sampled FSAs received a total of about SLL 2.0 billion at an average rate of $11 \%$ as refinance for on-lending to clients; while the FSAs gave out loans to clients at an average rate of $24 \%$.

Operating expenses ratio in 2010 shows that the amount expended per loan disbursed by the sampled FSAs was only $8 \%$; the figure almost doubled to $14 \%$ in 2011; rose slowly by just 1\% in 2012 and fell to $12 \%$ in 2013 . 
Starting with average disbursement of SLL 673,510 (approximately US\$153) in 2010, the average size of loan disbursed in the sampled FSAs more than doubled to SLL $1,409,379.10$ in 2011, fell slightly to SLL 1,355,030.41 in 2012, decreased further to SLL 975,724.32 in 2013. The sampled FSAs experienced stagnation in the growth of loan sizes and probably in the sizes of clients' income-generating activities as well. Perhaps the most obvious reason was that due to the growing average outstanding loans, the FSAs were unable to meet demands for bigger loans with the funds available.

Average loan outstanding in the sampled FSAs had been on the increase since 2010. According to the survey, the FSAs were on average able to collect only $22 \%$ of loans given out during the period to 2013. In 2010, 70\% of loans disbursed were uncollected, there was marked improvement in 2011 with $47 \%$ collected, the uncollected rose to $71 \%$ in 2012 and improved to 52\% in 2013 . The first and most obvious could be the poor intensity of the monitoring and collection effort. The second reason might be the timing of the loans disbursed; based on the duration period, loans issued by the latter period of the year could straddle into another year.

Job Creation: Loans accessed by clients of the FSAs led to consistent growth in incremental demand for labour days and employment effect in incremental person-years; as in 2013, there were about 1.1 million labour days and 4245 person-years created.

Profitability: According to the survey, the CBs started off with negative average profit of SLL 169 million in 2010. As expected, at the early stage of the programme intervention, operating expenses were above operating revenue; all profitability indices were negative in 2010. However, with improved performance, the operations of the CBs turned around and profit levels were good from 2011 to 2013.

Return on Capital Employed: Net operating profit margin in the sampled CBs grew by more than $105 \%$ to $29.91 \%$ in 2011 ; ROCE rose by almost $14 \%$ from $-8.49 \%$ to $5.22 \%$ and kept growing to $15.61 \%$ in 2013 . Also, ROA improved by almost $13 \%$ to $4.92 \%$ in 2011 and continued on the rise to $14.30 \%$ in 2013 way above the BSL minimum MIX requirement of $2.1 \%$.

Capital Adequacy: The survey found out that the sum of average paid-up share capital of the CBs was SLL 292,967,200; a shortfall of about SLL 700 million below the BSL minimum requirement of SLL1 billion. The situation was exacerbated by a weak Capital Adequacy Ratio (CAR) averaging just $2.51 \%$. The low CAR average was significantly influenced by the 2010 ratio of less than $1 \%$. However, the situation significantly improved in the subsequent years and the CAR now stood at almost $5 \%$ as in 2013. The implication is that as in 2013, the banks could afford to lose only $5 \%$ of their capital to withstand any shock.

Operational Self-Sufficiency: In the early period of 2011 and 2012 the CBs could only cover the $49 \%$ and $79 \%$ of operational expenses out of revenue from operations respectively. The ratio improved significantly in the 2012 and 2013 periods with the sampled CBs now able to cover $130 \%$ and $201 \%$ respectively 
surpassing the BSL OSS minimum Mix requirement of $112 \%$.

Portfolio at Risk: After a slight decrease in 2011, Portfolio at Risk had kept an upward trend over the years. The ratio grew by almost 3\% in 2012 to $8.21 \%$ and rose further to $9.65 \%$ in 2013 . The sampled CBs had written off no bad loans over the period under study but the growing PAR trend implies that the collection effort of the CBs could not keep pace with the growing loan disbursement. If the trend continues, sustainability would become an issue for the CBs and the likelihood for the write-off of bad loans in subsequent years could be inevitable.

Loan written-off: The sampled CBs made ample provision for bad loans over the years. In 2010, the CBs could cover more than $72 \%$ of their portfolio at risk. However, the ratio dropped drastically to its lowest of $8.55 \%$ in 2012 but rose to almost 22\% in 2013.

Yield on Gross Loan Portfolio: Cash revenue from loan portfolio of the CBs fell slightly from $16 \%$ in 2010 to $11 \%$ in 2011 but doubled to $22 \%$ in 2012 and rose by an additional $6 \%$ to $29 \%$ in 2013 .

Cost of Fund Ratio: The cost of re-financing the CBs had been extremely minimal according to data provided for the survey and when matched with the yield on loans showed a huge difference between the averages of $22 \%$.

Loan Size Progression: Starting with an average disbursement of SLL $1,014,285.71$ (approximately US\$230) in 2010, the average size of loan disbursed by the sampled CBs grew slowly to SLL 1,180,994.70 in 2011, and eventually rose to SLL $1,589,489.48$ in 2013.

Job Creation: Loans accessed by clients of the FSAs led to the consistent growth in incremental demand for labour days and employment effect in incremental person years; as in 2013, there were about 2.4 million labour days and 9174 person-years.

\section{Conflicts of Interest}

The author declares no conflicts of interest regarding the publication of this paper.

\section{References}

CGAP (2009). Financial Analysis for Microfinance Institutions. Published by the Comparative Group to Assist the Poor/World Bank.

https://www.cgap.org/sites/default/files/researches/documents/CGAP-Training-Financial -Analysis-Course-2009.pdf

Duramany-Lakkoh, E. K. (2020) The Effect of Fiscal Policy on Financial Sector Development In Sierra Leone: A Time Series Approach. International Journal of Development and Economic Sustainability, 8, 1-23.

Duramany-Lakkoh, E. K. (2021). Surveying the Socioeconomic and Business Dimensions of Microfinance Institutions in Rural Sierra Leone before the Ebola Outbreak: A Descriptive Statistical Approach. Journal of Financial Risk Management, 10, 172-186.

Ho, C., \& Zhu, D. (2004). Performance Measurement of Taiwan's Commercial Banks. International Journal of Productivity and Performance Management, 53, 425-434. https://doi.org/10.1108/17410400410545897 
Khan, M. Y., \& Jain, P. K. (1997). Management Accountancy, India. McGraw-Hill Publishing Company Ltd.

Levine, R. (1997). Financial Development and Economic Growth: Views and Agenda. Journal of Economic Literature, XXXV, 688-726.

McKinnon, R. I. (1973). Money and Capital in Economic Development (177 p). The Brookings Institution.

PRSP 1 (2005). Sierra Leone: Poverty Reduction Strategy Paper. International Monetary Fund, IMF Country Report, No. 05/191.

https://www.imf.org/external/pubs/ft/scr/2005/cr05191.pdf

Sangmi, M. D., \& Nazir, T. (2010). Analyzing Financial Performance of Commercial Banks in India: Application of CAMEL Model. Pakistan Journal of Commerce and Social Sciences, 4, 40-55.

Tarawneh, M. (2006). A Comparison of Financial Performance in the Banking Sector: Some Evidence from Omani Commercial Banks. International Research Journal of Finance and Economics, 3, 101-112.

Woller, G. (2000). Reassessing the Financial Viability of Village Banking: Past Performance and Future Prospects. Micro Banking Bulletin, Microfinance Information Exchange (MIX).

World Bank Group (2009). Financial Analysis for Microfinance Institutions. Consultative Group to Assist the Poor/The World Bank.

https://www.cgap.org/sites/default/files/CGAP-Training-Financial-Analysis-Course-20 09.pdf 


\section{Appendix 1: No of Active Borrowers}

Average number of youth that subscribed shares in the sampled FSAs was $43 \%$, of which female youth held $22 \%$ of the shares exceeding the $20 \%$ target. Furthermore, the project expected at least $30 \%$ of shareholders being women; the results show that $45 \%$ of the shareholders were women, exceeding target by $15 \%$. While the number of shareholders grew over the years, the FSA were able to attract more female clients than expected.

Similar results emerged from data on active borrowers showing that $58 \%$ of loans were granted to people 35 years and below of whom $31 \%$ were female youth. More than $60 \%$ of loans were granted to youth and female combined.

Similar to the FSAs, the sampled CBs attracted more female shareholders; out of an average of 967 shares, $26 \%$ were subscribed by female youth and $49 \%$ of all subscribers were female. However, in the case of CBs, more than 50\% (52\%) were youth. The CBs also met target of expected gender participation in loans granted. While number of female youth that received loans exceeded target by just a percentage point (21\%), the total number of women granted loans were $46 \% ; 16 \%$ above target (See Table A1).

Table A1. Number of shareholders and active borrowers.

\begin{tabular}{ccccccccc}
\hline & \multicolumn{3}{c}{ Average No. of Shareholders } & \multicolumn{3}{c}{ Average No. of Loans Granted } \\
\cline { 2 - 9 } & $\begin{array}{c}\text { Female } \\
\text { youth }\end{array}$ & $\begin{array}{c}\text { Male } \\
\text { Youth }\end{array}$ & Women & Men & $\begin{array}{c}\text { Female } \\
\text { youth }\end{array}$ & $\begin{array}{c}\text { Male } \\
\text { Youth }\end{array}$ & Women & Men \\
\hline FSA & 16,095 & 15,296 & 31,967 & 39,597 & 3140 & 2783 & 5014 & 5157 \\
Actual (\%) & $22 \%$ & $21 \%$ & $45 \%$ & $55 \%$ & $31 \%$ & $27 \%$ & $49 \%$ & $51 \%$ \\
Target (\%) & $20 \%$ & $30 \%$ & $30 \%$ & $70 \%$ & $20 \%$ & $30 \%$ & $30 \%$ & $70 \%$ \\
CB & 967 & 979 & 1866 & 1907 & 725 & 810 & 1630 & 1880 \\
Actual (\%) & $26 \%$ & $26 \%$ & $49 \%$ & $51 \%$ & $21 \%$ & $23 \%$ & $46 \%$ & $54 \%$ \\
Target (\%) & $20 \%$ & $30 \%$ & $30 \%$ & $70 \%$ & $20 \%$ & $30 \%$ & $30 \%$ & $70 \%$ \\
\hline
\end{tabular}

Source: Researcher's data.

\section{Appendix 2: Sector Analysis of Loans Granted by Institutions}

During the period of the survey, five sectors benefited from loans by the sampled FSAs and CBs including trade and Commerce, Agriculture, Manufacturing and Processing, Transport and Utility, Building and Construction and Other Emergency loans. Over the years, the CBs and FSAs in the sample received incomes in the form of interest paid at rates negotiated by clients. These incomes were reported in the form of Term Interest on Loan, Commitment and Assurance Fees, Interest Charge, Commission on Turnover and Interest on Overdraft.

Appendix Table A2 gives total loans disbursed and interest received per sector by the sampled CBs and FSAs.

Value of loans granted: More than SSL 25 billion was granted to all the sectors by the sampled FSAs and CBs over the four active years with more than $60 \%$ provided by the CBs. As shown in Table A2, bulk of the loans was given for trade and commerce. 
Table A2. Loans disbursed and interest received by FSAs and CBs.

\begin{tabular}{ccccc}
\hline \multirow{2}{*}{ Sector } & \multicolumn{2}{c}{ FSAs } & \multicolumn{2}{c}{ CBs } \\
\cline { 2 - 5 } & Amount & Interest & Amount & Interest \\
& SLL000 & SLL000 & SLL000 & SLL000 \\
\hline Trade and Commerce & $9,492,000$ & $2,014,497$ & $11,080,752$ & $1,567,333$ \\
Agriculture & 498,869 & 88,778 & $3,165,817$ & 399,314 \\
Manufacturing \& Processing & - & - & - & - \\
Transport and Utility & 52,990 & 10,940 & 323,158 & 27,317 \\
Building \& Construction & - & - & 51,960 & 3413 \\
Other Emergency & $1,526,582$ & 176,052 & $4,475,560$ & 627,419 \\
\hline
\end{tabular}

Source: Researcher's data.

More than $82 \%$ of all loans given by the FSAs to clients went in support of business development while only $22 \%$ were given to agriculture, transport and utility and emergency. The data showed that loans given by the FSAs for emergency purposes which included salary advance and loans to institutions such as schools and religious bodies, far exceeded loans given out for agricultural purpose, accounting for only about $4 \%$ of total loans granted.

Also result obtained for CBs attributed $58 \%$ of loans to trade and commerce. However, though also slightly lesser than loans given for emergency purpose, $17 \%$ of all CBs loans were given for agricultural purpose; implying that the sampled CBs granted more loans in support of agriculture than the FSAs, which could be as a result of the level of capitalization and flexibility in loan repayment duration of the CBs.

\section{Appendix 3: Overview of Sierra Leone Economic and Finan- cial Sector}

Interest received by sector: The total of SLL 2.29 billion and SLL 2.62 billion interest on loans given out were received by both FSAs and CBs respectively from all sectors during the period 2010 to 2013. Obviously, interest received form trade and commerce amounted to SLL 1.5 billion, formed the largest of $58 \%$ of the total interest received. Interest on agriculture loans contributed only $15 \%$ while emergency loans earned $24 \%$ of the total (See Figure A1).
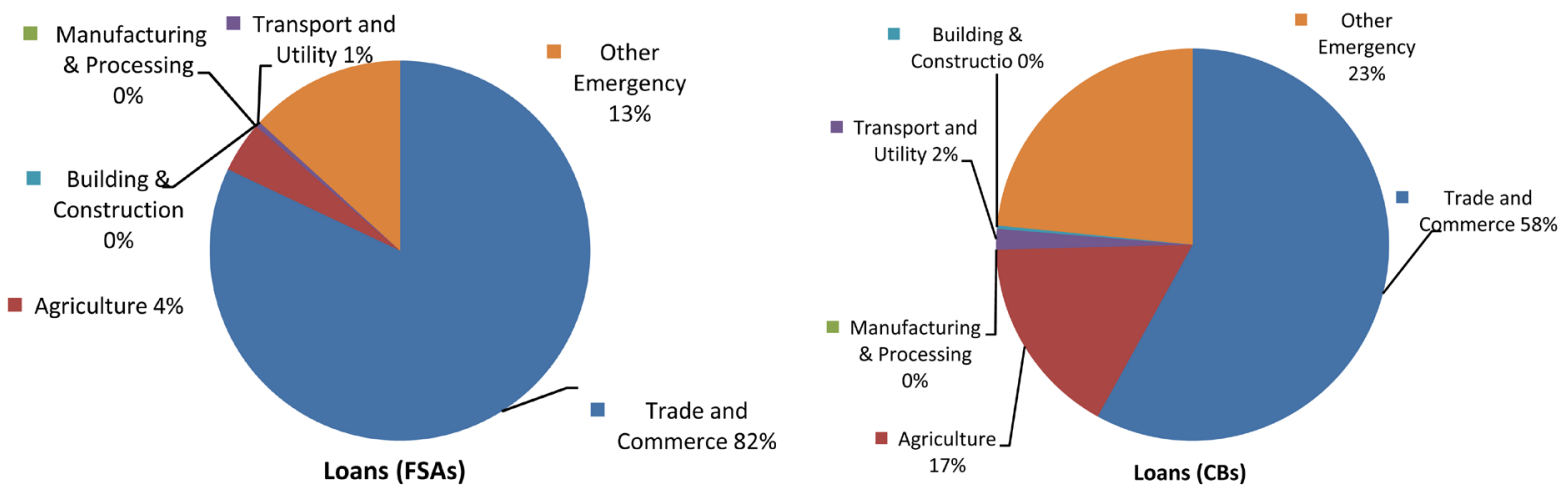

Figure A1. Loans granted according to sectors. Source: Researcher's data. 


\section{Appendix 4: Overview of Sierra Leone Economic and Finan- cial Sector}

After the end of the civil war in 2001, the economy of Sierra Leone was in a bad shape. The country's GDP per capita of approximately US $\$ 750$ at the start of this civil war in 1992, dropped to $\$ 600$ in 2001 . However by the end of 2013, with the sound financial sector reform and economic progress, GDP per capita (PPP) was $\$ 1544$ and ranked ahead a few other sub-Saharan countries including Guinea, Liberia and Ethiopia.

Sierra Leone's economic development has always been lead by overdependence on mineral exploration especially diamond. Successive governments and had always seen mining sector (diamond and gold) as the major investment and earner of foreign exchange. However, in the 1970s and early 1980s a decline in the mining sector led to stagnation in economic growth, as the country lost its economic base, exchange rate of the Leone fell significantly against the major currencies; and being an import dependent country, government budget deficits rose sharply leading to general decline in economic activities and a serious decline in the provision of necessary infrastructure to support socio-economic development.

In recent years, resumption of iron ore mining has provided some respite in the country's economic stress. The mineral has dominated the country's export and given rise to optimistic projection with potential to drive the GDP growth to one of the highest in the world. Even though agriculture has been dominant as a major sector of the country's national income earner, it has always been relegated for commodity products, industrial development and sustainable investment projects.

Both inflation and fiscal deficit surged over the years; inflation fell from 18.5 in 2011 to 7.1 in 2013, while fiscal deficit reduced from $4.5 \%$ to $2.3 \%$ of GDP in the same period. In the most recent years, total government expenditure consumption and transfer payments amounted to $21 \%$ of GDP. Since the introduction of the Goods and Services Tax in 2010, revenue from taxation has become fundamental part of Sierra Leone revenue mobilization. After the inception of the National Revenue Authority in 2003, which brought about significant restructuring in management of tax collection process, tax revenue continued to grow and almost doubled in 2009 to 2011 by almost $99.40 \%$ (from Le 698 billion to Le 1395 billion) and continued to increase by $26.68 \%$ in 2012 .

The financial sector continued to deepen led by the expansion of the banking sector; licensed commercial banks increased to 13 as at end 2013 coupled up with continued increase in opening of 80 new branches nationwide. There are 4 community banks were also licensed added to the existing 6 initially managed and 9 registered microfinance institutions. The IFAD's RICIP Community Banks (CBs) and Financial Services Associations (FSAs) have given new dimension to financial sector development of the county over the past five years. Apart of mainstream banks, there are 2 discount houses, 8 insurance companies which 
are mainly located and operating in the capital Freetown. In 2008, the Sierra Leone stock exchange was granted licence to operate with logistics support and initial capital provided by Bank of Sierra Leone to meet the start-up costs and minimum requirements for the first year of operation. Home Mortgage and Savings Bank was also granted licence to operate as a primary mortgage dealer in the financing of home mortgages backed by its appropriate guidelines.

In view of the increasing number of financial institutions and products, the Bank of Sierra Leone and the IMF implemented the interim financial sector development strategy followed by a comprehensive financial sector development plan supported by the World Bank's Financial Sector Reform and Strengthening Initiative (FIRST) and the Microfinance Investment and Technical Assistance Facility (MITAF). Also, as a response to the emergence of new sophisticated and complex financial products and their associated risks, BSL enforces the capital requirements for commercial banks and other deposit taking institutions and moves away from compliance-based to risk-based supervision.

In the financial market, the three-month treasury bills rate declined to about $10 \%$ in 2013 from $14 \%$ in 2012 due to the reduction in government domestic borrowing. However, commercial banks interest rates remain very high at above $26 \%$ depending on the profile of the financial instrument and perhaps the customers; overdraft lending rate ranged between 25 - 31 percent during the 2013 year. Despite the expansion of both formal and informal banking system, majority of Sierra Leoneans still operates outside the banking system. Most Sierra Leoneans are still unable to obtain credit for significant business projects, which tends to undermine private sector development. 